A partnership approach to developing student capacity to engage and staff capacity to be engaging: opportunities for academic developers

Roisín Curran $^{\mathrm{a}^{*}} \&$ Luke Millard ${ }^{\mathrm{b}}$

${ }^{a}$ Staff Development, Ulster University, Northern Ireland, UK; ${ }^{b}$ Centre for Enhancement

of Learning \& Teaching, Birmingham City University, England, UK

*Corresponding author. Email: $\underline{\text { r.curran@ulster.ac.uk }}$ 
Roisín Curran is an academic developer based in the Staff Development Unit at Ulster University. She is a tutor on the Postgraduate Certificate in Higher Education Practice and one of the leads on the University's Professional Development \& Recognition Scheme. She is project lead on the "What works? Student Retention \& Success Change Program (2012-15)" and is a Principal Fellow of the Higher Education Academy.

Luke Millard is Head of Student Engagement at Birmingham City University. He is a tutor on the Masters in Education, project lead on the "What works? Student Retention \& Success Change Program (2012-15)" and has a particular interest in student engagement and its value in student transitions and the first year experience. He is also a Principal Fellow of the Higher Education Academy. 


\title{
A partnership approach to developing student capacity to engage and staff capacity to be engaging: opportunities for academic developers
}

\author{
Many higher education institutions are adopting learning and teaching approaches \\ that embrace "students as partners". This can be met with trepidation by academic \\ staff and students. The purpose of this paper is to demonstrate, through two UK- \\ based institutional case studies, that a partnership approach provides an \\ opportunity for staff and students - where each appreciate the others' perspective \\ and the barriers to learning are reduced. We propose five learning points for \\ academic developers to reflect and act upon to get to the very heart of how we \\ might achieve and sustain partnership work.
}

Keywords: academic developers; change; learning and teaching; "students as partners"; transformational

\section{Introduction}

In the new higher education world of expanding numbers and widening student demographics, engaging with students as partners provides a significant opportunity for academic developers. We will explore how the "students as partners" approach can lead to more motivated learners and enthused academic staff, and as a result, consider how academic development teams can best position their work to support academic staff and students seeking to initiate change through this dialogue. In doing so, we address what Healey, Flint, and Harrington (2014) highlight: that the understandings of the impact of partnership work - for students, staff, institutions, society more broadly - remain relatively poor, and there is a need for a greater evidence base around the outcomes of partnership.

Literature asserts that in order to promote deep learning for all students, it is desirable to move from a content-focused, teacher-led climate to learning situations which focus on what the student does and engages students in active learning (Biggs and 
Tang, 2011; Chickering \& Gamson, 1987; Entwistle, 2009; Thomas, 2002). This focus on students acknowledges that learning is a joint activity, starts from the student's experience, and changes the learner's perspective on knowledge (Mezirow, 1991; Prosser and Trigwell, 1999). Learning therefore is less about the absorption of knowledge and more about how we set the right conditions for conceptual change to take place. According to Biggs and Tang (2011) conditions for such a change include student motivation and students working collaboratively with others, both peers and teachers.

Research demonstrates that teachers and institutions create a certain learning climate through interactions with students which in turn has a strong effect on students' learning (Gardner, 1993; McGregor, 1960; Pintrich \& Schunk, 2002). The learning climate that promotes independent lifelong learners is one that is based on high trust, and the extent to which we lean more towards this trusting climate translates into action at all levels of student-teacher interaction (Biggs \& Tang, 2011). Taking this a step further, if we engage our students as partners in learning and teaching and this partnership is based on respect, reciprocity, and shared responsibility, then we can make learning and teaching more engaging and effective for students and staff (Cook-Sather, Bovill \& Felten, 2014).

Healey et al. (2014) state that

Partnership is understood as fundamentally about a relationship in which all involved - students, academics, professional services staff, senior managers, students' unions, and so on - are actively engaged in and stand to gain from the process of learning and working together. Partnership is essentially a process of engagement, not a product. It is a way of doing things, rather than an outcome in itself (p.12).

The Universities collaborating in this paper see the "students as partners" ethos as being instrumental in enhancing student engagement activities. Implications for academic developers are outlined with suggestions on how leadership may be provided in 
developing and supporting academic staff to improve academic student engagement (Healey et al., 2014; Jones, 2012; Thomas, 2012).

\section{Background}

In 2012, Birmingham City University (BCU) mentored Ulster University through the Higher Education Academy (HEA) Students as Partners Change Program. This change program provided advice and support for 10 Universities seeking to engage in "students as partners" activities. This relationship further developed, in 2013, when both Universities were selected (along with 11 others) to take part in the second phase of the HEA's What Works? Student Retention and Success Change Program (SRS). The change program sought to improve the strategic approach to the engagement, belonging, retention, and success of first year students through the implementation of interventions in the areas of induction, active learning, and co-curricular activities in three selected discipline areas. A key principle of this change program was that it adopted a "students as partners" approach.

The Universities are located in different countries, but they share similar issues and student populations. BCU works with 24,000 students across multiple campuses within England's second city, where the focus is upon transforming students through excellence in practice-based education, research, and knowledge exchange. Ulster is a regional, widening participation university and currently has over 26,000 students enrolled across four campuses in Northern Ireland. The student population is mainly made up of local students and the University's mission is "Professional Education for Professional Life".

The foundation for collaboration between the universities was built on a shared goal to foster a greater sense of belonging and community (Thomas, 2012) across a 
student population that was dominated by commuter based students who all too readily only attended university for classroom-based activities. Changing the "Them and Us" dynamic had been one of the key drivers for the creation of student engagement activities at BCU in 2008; wishing to emulate BCU's successes, Ulster since 2013 aspired to inculcate a partnership approach between students and staff. As collaborators in this paper we are based within each University's staff development service which means that we also share an agenda around initiating change through academic development. As a result we saw the possibility of utilizing student engagement as a mechanism for creating a student experience led internal quality enhancement system (Bartholomew et al., 2013) whereby students and staff could identify issues that had a detrimental impact on the learning experience and develop interventions that enhanced the quality of the student learning experience and the sense of learning community. The development of schemes to support such interventions and the creation of capacity to manage such change were some of the key issues for us as collaborators to resolve. In this paper we draw together and reflect on our own university initiatives presented here as case studies.

\section{Case Study 1: Birmingham City University}

The BCU approach to working with students began in 2008 (Brand, Millard, Bartholomew \& Chapman, 2013; Freeman, Brand, Millard, \& Chapman, 2014; Nygaard, Brand, Bartholomew, \& Millard, 2013) and focuses on employing students in pedagogic projects to work alongside academic staff and professional staff to improve the student learning experience. A vital piece of the journey in creating this approach was engagement within BCU Students' Union (Chapman, Blatchford, \& Hughes, 2013). Drawing upon the imagination of the Students' Union (SU) enabled work at BCU to swiftly make significant strides at local and management levels, and saw substantial enterprise develop that runs to this day. The principle of student employment is now 
embedded across the University and recognizes the value of their contribution. It is founded upon the belief that the University wishes to engage with the entire student population and not just those students who can afford to give up time to work as a student academic partner.

Engagement activities over the past five years at BCU have resulted in 557 staff/student partnership projects that have produced 1200 student jobs. Roughly half of the some 60 projects each year focus on improving student learning at the programme or modular level, while the other half involve senior students mentoring more junior peers. For any project to be funded the application has to demonstrate a meaningful partnership between students and faculty and clearly identify an intervention that will improve the student learning experience.

The evidence provided by BCU in this paper is drawn from a number of sources. Evaluation reports from the six years of student engagement work at the University have been reviewed. These reports were founded upon a case study methodology and were most effectively brought to life within the publication Student Engagement: Identity, Motivation and Community co-written by staff and students (Nygaard et al., 2013). In addition, we have drawn upon an internal survey of students involved in student employment activities at BCU. The survey explored student attitudes and motivations towards student employment on campus while also uncovering the variety of external impacts that challenge the standard perception of a full-time student. 200 students were sent the survey link in February 2014 and it received a response rate of $40 \%$.

Chapman et al. (2013) note that "over the last decade the UK higher education sector has witnessed an increased focus on student engagement and an emergent repositioning of student and staff relationships" (p.271). At BCU, student partners report that being able to work alongside staff "demystifies" their view of what it means to be a 
staff member at the University. From this increased understanding comes a realization that staff members are people not too dissimilar from themselves. This allows student partners to feel more at ease when dealing with staff members.

Certainly it would appear that staff value the insight into the student perspective. While no student will ever be entirely representative, they do however bring a way of thinking that more closely reflects those of their peers, based on current or recent experience as opposed to that which is recalled from many years past. Some staff have also come to the realization that such meaningful conversations are important to ensure a true understanding of student perspectives is achieved in order to make more informed decisions for both the University and its students.

The blurring of roles is an inevitable and often welcome consequence of students and staff working together in new ways. The survey of students employed at BCU revealed that $63 \%$ saw themselves as some sort of hybrid between a member of staff and a student. $20 \%$ still saw themselves as students while they worked for the University and $17 \%$ viewed themselves as being members of staff. The fact that students are employed through the University's human resources processes and receive a staff email address might be expected to strengthen their identity as a professional staff member, but it would appear from our evaluations that the majority cannot make that separation from their main role as a student. Mentoring projects deliberately position the student in a supplemental instruction or guidance role, blurring the strict lines between teacher and student. We would argue that this is a welcome ambiguity as many seek to break down the barriers between staff and students or "them and us". This can result in challenges for both parties (Welikala \& Atkin, 2014).

It can be speculated that there is some residual benefit from this positional change through the student partner showing other students how they can easily converse with 
staff members of the University. Similarly it can be expected that staff who have more interaction with students (and student partners) would be more at ease in interacting with them and are more likely to consider or even ask for student input into program related decisions. These findings were reflected in the survey of BCU students employed on pedagogic projects where $68 \%$ agreed or strongly agreed that as a result of their employment they worked harder at their studies. Much in the same way that a deeper understanding helps break down the barriers, it can also allow for a closer relationship between staff and students through a more meaningful appreciation of each other.

For BCU students directly involved in partnership work, nearly all the examples demonstrate how partnership work positively impacts on engagement. As one BCU student explained in her project evaluation:

The main benefit of my student employment is the process of self-evaluation. I have been able to identify my strengths but also acknowledge my limitations and want to work on these to improve and grow as an individual which is a good feeling.

Additionally, many students report an improved sense of community. At BCU the student survey revealed, perhaps unsurprisingly, that $95 \%$ of students felt they had a better relationship with staff through having worked on campus and $93 \%$ felt they had a greater sense of belonging to the university.

For students the formalization of the employment process at BCU has also impacted on the personal development of students and their employability skills, particularly through an enhanced level of professionalism. Completion of job application forms, interviews, project management, time keeping, and leadership are all experiences that instill the professionalism we seek to develop in all our students.

There are many benefits for staff outlined elsewhere, but there is also the simple pleasure in seeing a student develop beyond what you may feel you can achieve in a 
classroom. Changing practice is clearly not comfortable for all staff and presents a real challenge. BCU staff partners, Gough, Morris, and Hession (2013) comment that:

It is refreshing to be able to test out ideas prior to delivery to the wider student cohort, particularly, for projects that are designed with the student experience in mind. They soon tell you if you get it wrong and often come armed with much more engaging solutions ( $\mathrm{p}$. 173).

However, at BCU the message is clear that the benefits outweigh any discomfort. As the BCU staff partners, Vaughan, and Williams (2013) state:

It has been enjoyable, rewarding and at times challenging to keep up with the students' ideas. I wish we had done this a long time ago (p. 33).

The experiences of staff and students at BCU show that working together in partnership provided the opportunity to see things from the others' perspective, to discuss issues and challenges in a more collegial way, and to develop trust relationships. The "them and us" dynamic has started to be eroded through a greater sense of collaboration and community. The BCU and Ulster collaboration, which started in a mentoring capacity, has provided BCU with the opportunity to reflect on their approaches to partnership and to consolidate these at a more strategic level.

\section{Case Study 2: Ulster University}

Student engagement initiatives at Ulster have taken a slightly different form from those at $\mathrm{BCU}$, and although there have been approaches that have involved students as partners for many years, such as problem-based learning (Hack, McKillop, Sweetman, \& McCormack, 2015) and peer-assisted study sessions (Keenan, 2014), these have mainly been instigated and led at a local subject or program level. The focus for this case study centers on the What Works? Student Retention \& Success (SRS) Change Program (2012 - 2015), which has promoted a "students as partners" approach across the institution, is 
strategically aligned to the University's Learning and Teaching Strategy, and has senior management support. The overall aim of the Change Program is two-fold; firstly to improve the student first-year experience both in terms of retention and success and secondly to evaluate, learn from, and disseminate effective practice in the process of change through the adoption of a partnership approach. In pursuit of this aim, Ulster, like BCU, works closely with its Students' Union, building on previous collaborations that supported curriculum design and student-led awards.

This case study reports on the experiences of staff and students involved in the seven discipline teams of the SRS Change Program. The students involved are either first, second, or final year students currently enrolled in mainly full-time undergraduate courses and the staff involved are the tutors involved in the program. This investigation involving semi-structured interviews was carried out to build on the findings of the BCU survey and sought to test if the positive impact on the learning climate at BCU was being replicated at Ulster.

\section{Data Collection - Semi-structured Interviews}

In order to focus on the meanings that people bring to situations (O'Donoghue, 2007; Savin-Baden \& Howell Major, 2013), how staff and students lived the experience of being a partner (Denicolo \& Becker, 2012; Kvale, 2007) and the impact of this in relation to the individual, one-to-one semi-structured interviews were carried out. Purposive sampling was used and interviews were carried out in Spring 2014 with one student and one staff member per discipline team $(n=14,7$ staff and 7 students $)$ to ensure that all discipline teams and all four campuses were represented. While 14 interviews may seem small in some spheres of research, within the context of this qualitative study the stratified purposeful sample is representative of the subgroups and facilitates comparison across the disciplines and campuses. 
In reporting qualitative comments, the following convention is used:

$\mathrm{T}$ for tutor, interview number, $\mathrm{M} / \mathrm{F}$ for gender, number of years' experience

$\mathrm{S}$ for student, interview number, $\mathrm{M} / \mathrm{F}$ for gender, year of study

The interviews were enlightening and indicated the value of this work in changing the dynamic of the student and staff relationship. As one member of staff highlighted;

They see me as more human and approachable. I see them in the same way. I don't see them as a student cohort now, I know them individually and their capabilities and personalities a bit better. $(\mathrm{T} 2, \mathrm{M}, 8)$

A part-time student articulated his changing perceptions;

I possibly took it for granted they are the teacher; you are the student and it's a very well defined relationship. Outside of this it's interesting, the guys are just like me and like my colleagues [works in a bank] and it's useful to see them more as people and not just as lecturers. (S5,M,2)

A different student demonstrated how involvement in partnership provides an insight into the complex world of higher education and breaks down the "them and us" perception:

University does care - I came in with the opinion that it's about money - that has drastically changed - the majority of staff are trying to make the experience better. This has been a more holistic experience. I would have thought that HE was just about stuffing students with knowledge but it's much broader than that. (S6,M,1)

For both staff and students, a new type of relationship can be challenging but rewarding:

The students were full of ideas, it didn't really reflect what I wanted to do but I stood back and let them run with it and my role became - a facilitator. (T3,M,12)

The building up of trust relationships and the creation of a community of practice is also evident: 
This is about trusting the student to define what they want to do [project briefs]. It's like a parent letting their children learn how to fly. It's about determining a time line - its learning to be an independent learner. It's about not being too over bearing but providing an answer when they need it. Trust is key. (T5,F,26)

One of the most transformative outcomes of staff student partnership can be realized through the increase in student motivation and the knock-on effect on their peers:

I feel as if I'm doing a good job, I think it's maybe helped me to settle into university...for me personally it's given me more involvement. I've even noticed a change in myself that I feel as if I'm definitely going to finish this and there are others who aren't in this kind of role and they are feeling a bit 50/50. (S1,F,1)

It rubs off on the other students - when they hear questions being asked, it gives them confidence to speak up. $(\mathrm{S} 6, \mathrm{M}, 1)$

Additionally staff have given us many examples of how the staff student partnership has prompted them to re-think what they do and as described by Van Schalkwyk, Cilleirs, Adendorff, Cattell, and Herman it has created the "sort of enabling environment where university teachers will be able to talk about what they do, slow down and reflect" (2012, p 149).

We use a lot of group work now, we have a first year project, various activities so that the students get to know each other. Students meet socially in the learning environment - linked to the sense of belonging. Our students know each other well now better than before. This makes a difference, we noticed in the past that groups of students who commuted wouldn't have mixed with the others but now they do. $(\mathrm{T} 4, \mathrm{M}, 20)$

I think I'm now more open to students. I'm probably not as judgmental; I'm more open to hearing what they have to say and taking on things and doing something if we can...They will all have different journeys, rather than looking at people as a cohort, I see them as individuals who have their own hopes and aspirations. How I work with the students probably has changed. $(\mathrm{T} 3, \mathrm{M}, 12)$ 
Our reflections, on supporting our academic colleagues and students to engage in staff student partnerships, and drawing on the two case studies presented leave us in no doubt that a partnership approach provides a learning opportunity for both staff and students - where each can see things from the others' perspective and the barriers to learning can be reduced. We do not suggest that students as partners is a panacea for all the challenges with engaging students but we believe that it is enabling in terms of motivating students to engage and prompting staff to create learning climates based on trust and shared responsibilities.

\section{Implications for Academic Developers}

Practical strategies for developing staff student partnerships have been put forward by Cook-Sather et al. (2014) which provide guidance for academic staff around getting started, sustaining, and deepening staff student partnership practices, and negotiating roles and power. However, from the perspective of academic developers, and to address a paucity in the research (Felten, Bovill, \& Cook-Sather, 2013; Healey et al., 2014) we wish to share what has worked effectively for us by suggesting some critical success factors for the promotion of a staff student partnership approach across an institution based on the case studies we have presented above which represent 7 years of work, data collection, reflection, and discussion between ourselves as the collaborators in this paper.

We suggest the following factors should be considered and led by academic developers wishing to initiate and sustain staff student partnerships. In so doing we recognize that all institutions are different and any change inevitably generates unique challenges in different contexts. However, with that caveat, we propose the following:

1. Develop a strong working relationship between academic development and the SU;

2. Embed Students as Partners into University strategy and policy documents; 
3. Explore opportunities to deepen student learning from work-based partnerships;

4. Disseminate effective Student as Partners approaches;

5. Recognize and reward partnership work.

\section{Develop a strong working relationship between academic development and the Students'Union.}

The role of the SU, which has been key to the developments at BCU, is crucial. As Chapman et al. (2013, p.275) notes 'a move to a role that proactively enhances the quality of learning and teaching through formal academic partnership projects with the university was innovative for BCU and the sector'.

This has also been recognized by the National Union of Students (NUS) at a national policy level within its 2013 publication, Manifesto for Partnerships. As Rachel Wenstone, the Vice President (HE), states in the introduction 'Student engagement is a great concept but it needs to be deployed to radical ends. Students as partners is not just a nice-to-have, I believe it has the potential to help bring about social and educational transformation' (p.1).

Equally at Ulster, the strong working relationship and joint ownership and collaboration by academic development and the SU on partnership projects has been key to driving this agenda forward. In both Change Programs, the SU's student engagement manager, and an academic developer are members of the core team that lead on driving these initiatives. Additionally the SU are involved in all strategic committees and working groups across the institutions, not just as a token member but as an active participant representing the wider student perspective.

In our experience, the key benefit here is that if an academic development unit representing the university's learning and teaching philosophy and the SU representing 
the student voice collaborate to engender change, this partnership can provide a coherent and strong perspective that can be persuasive to decision makers in the University.

\section{Embed Students as Partners into University strategy and policy documents.}

We have found that embedding a partnership ethos into universities' key strategies is an enabler for staff and students to work towards a partnership approach and can bring about a shift in institutional thinking. At Ulster, a consultative process with staff and students in 2012-13 resulted in the development of a key strategic aim now embodied in the new Learning and Teaching Strategy "to provide transformative, high quality, learning experiences through the promotion of meaningful staff student partnerships that engender a shared responsibility" (Ulster, 2013, p.4).

At BCU the success of the student academic partners in achieving external recognition through the Times Higher Education award, Quality Assurance Agency (QAA) commendation in inspection reports, and the first NUS/Higher Education Academy institutional partnership award, meant the University recognized that it had created something of a unique identity. This was further acknowledged within its Strategic Plan 2020 which aspires to BCU being "recognized as the sector leader in student engagement". In addition the University now wishes to make itself distinctive by ensuring "students have a sense of ownership in their University". The weight of the institution behind the philosophy of students as partners has been a crucial element to the success and sustainability of this work at BCU, partnership is now interwoven within the structures and processes of the university which makes it more difficult for academic staff to avoid engagement than to participate. 


\section{Explore opportunities to deepen student learning from work-based partnerships.}

At Ulster, final year student mentors are paid to coach first years in computer laboratories on particularly challenging programing languages. Evaluation of this initiative has shown that because the mentors can relate well to the year 1 students from their own experiences on the same course, their closeness in age, and their recent completed placement, they are well placed to assist year 1 students and provide examples of industrial expectations as students progress through the knowledge and practical skills of the course.

BCU offers around twenty student employee roles from technical assistants and researchers to administrators and ambassadors. The benefits of students engaging in pedagogic projects on campus are multi-layered and can impact on motivation, sense of belonging, and ultimately student success. These benefits are also reflected in a Higher Education Funding Council (2006) report where the report's authors expressed heighted an unexpected outcome:

\footnotetext{
A point repeated many times by students in interview was, mostly, they believed that working as well as studying helps make them better students. This was a surprising finding. Students explained that they managed their time better because they had to. Students believed they had a better experience and led fuller lives than students who did not work (p. 9).
}

The interesting challenge for the sector is how we recognize this employment. Perna (2010) saw employment and working alongside your studies as being the norm for US students, and suggested that those universities that did not as "failing to recognize that higher education is generally not the primary life environment of working students" (2010, xviii). Additional employability awards offer possible recognition, but there are clear opportunities to draw upon the lifewide experiences students gain in all forms of 
employment and reflect these within the seminars and assessments that students undertake. The challenges for academic developers are to support academic staff in recognizing this skill development in students and to seek opportunities to embrace it within curriculum developments.

\section{Disseminate effective Student as Partners approaches}

This can be achieved in different ways and is crucial to recognizing the effective practice of staff and students. Hearing about the impact of partnership work from both a staff and student perspective can be motivating to others contemplating adopting a similar approach. At Ulster and BCU, we have provided opportunities for dissemination through:

a) Adapting course content in relation to student engagement in pedagogic program to include "students as partners" approaches and case studies.

b) Relating internal conference themes to staff-student partnership and putting out calls for examples of effective practices.

c) Inviting visiting professors with a proven track record of effective partnership approaches to address staff and students within our institutions.

d) Using opportunities such as program approval and revalidation to influence program teams to embed a "students as partners" philosophy.

\section{Recognize and reward partnership work}

Recognition and reward can be powerful ways of providing an answer to "What's in it for me?" For staff, partnership may seem like a lot of extra hard work and a step into unfamiliar territory, particularly if they perceive that there is no real need to change the 
status quo. Therefore it is important for universities to consider how to encourage both extrinsic and intrinsic motivation for staff and students to engage in partnerships. For instance, at Ulster, recognition for students is available in the form of eligibility to work towards the Ulster Edge award. This is an award achievable through reflection on four extra-curricular activities. Students are also encouraged to co-present and co-write with their academic colleagues on effective practices. BCU's work in student engagement is showcased in a book, "Student Engagement - Identity, Motivation and Community" (Nygaard et al., 2013), which contains 15 chapters which were all collaboratively written by students and staff. Reward may equally be realized through paid work or through the realization and acquisition of new skills which develop the whole person.

Staff can be encouraged to reflect on their changing practice and use this to seek recognition either through dissemination or through other routes to recognition. For example, in the UK staff could seek to use their effective partnership practice as evidence for one of the categories of fellowship of the Higher Education Academy, aligned to the UK Professional Standards Framework. This framework can also be used along with the students as partners conceptual model as suggested by Healey et al. (2014, p.6). This partnership approach would suggest that students should also be recognized for such engagement and BCU has now validated, through the Staff and Educational Development Association (SEDA), a student fellowship award.

\section{Conclusion}

Promoting a "students as partners" ethos is challenging for staff and students and particularly for academic developers when "learning and teaching institutional priorities will continue to change before new practices can be implemented and become routine" (Brew \& Cahir, 2013, p.350). In addition to this, many institutions' senior managers are 
preoccupied with the bottom line, meaning that partnership programs may need to generate hard numbers to demonstrate impact rather than relying on "qualitative research methodologies and methods to assess and analyze student and staff experiences and outcomes" (Felten et al., 2014, p1). Within a metric-based culture, staff developers need to systematically and creatively measure the outcomes of partnerships. In this paper we have provided some examples of how that success can be described and how initial successes can be embedded within organizational norms.

We do this in the knowledge that sustainability is key and institutional adoption within key strategies, influenced by the weight of coherent evidence from staff and student bodies drawn from activities that enhance both the student and staff experience, is crucial if partnership is to successfully and productively thrive in any university. 


\section{References}

Bartholomew, P. Brand, S., \& Millard, L. (2013). Quality Enhancement through Student Engagement. In C. Nygaard, N. Courtney \& P. Bartholomew (Eds.), Quality Enhancement of University Teaching and Learning (pp.199-216). Faringdon: LIHE/Libri.

Biggs, J. \& Tang, C. (2011). Teaching for Quality Learning at University. $4^{\text {th }}$ edn. Berkshire: McGraw-Hill.

Brand, S., Millard, L., Bartholomew, P. \& Chapman, P. (2013). Students as Academic Partners: a three layered approach for enhancement. In E. Dunne \& D. Owen (Eds), The Student Engagement Handbook: Practice in Higher Education (pp.477-492). Bingley UK: Emerald Group Publishing Ltd.

Brew, A. \& Cahir, J. (2013) Achieving sustainability in learning and teaching initiatives. International Journal for Academic Development, 19:4, 341-352, DOI: 10.1080/1360144X.2013.848360.

Chapman, P., Blatchford, S. \& Hughes, E. (2013) Lightening up the dark side: a partnership approach between a students' union and the university. In C. Nygaard, S. Brand, P. Bartholomew \& L. Millard (Eds.), Student Engagement: Identity, motivation and community (pp.271-290).Oxfordshire: Libri Publishing.

Chickering, A. \& Gamson, Z. (1987). Seven Principles for Good Practice in Undergraduate Education, American Association for Higher Education Bulletin, 39: 3-7.

Cook-Sather, A., Bovill, C. \& Felten, P. (2014). Engaging Students as Partners in Learning and Teaching: A Guide for Faculty. San Francisco, CA: Jossey-Bass.

Denicolo, P. \& Becker, L. (2012) Developing Research Proposals. London: Sage.

Entwistle, N. (2009) Teaching for Understanding at University: Deep Approaches and Distinctive Ways of Thinking. Basingstoke: Palgrave Macmillan.

Felten, P., Bovill, C. \& Cook-Sather, A. (2014) Engaging students as partners in learning and teaching (1): benefits and challenges - what do we know. [ICED 2014 Conference Proceedings]. Retrieved from http://www.iced2014.se/proceedings/1194 Felten.pdf

Freeman, R., Brand, S., Millard, L. \& Chapman, C (2013). Student Academic Partners: student employment for collaborative learning and teaching development. Innovations in Education and Teaching International, 51:3, 233-243, DOI:10.1080/14703297.2013.778064

Gardner, H. (1993). Frames of Mind: The Theory of Multiple Intelligences. New York: Basic Books.

Gough, K., Morris, J. \& Hession, A. (2013). Media Industries Beyond the Curriculum: Motivating Blended Professionalism for Enhanced Student Engagement and

Employability. In C. Nygaard, S. Brand, P. Bartholomew \& L. Millard (Eds.), Student Engagement: Identity, motivation and community (pp.165-183).Oxfordshire: Libri Publishing.

Hack, C., McKillop, A, Sweetman, S. \& McCormack, J. (2015). An evaluation of resource development and dissemination activities designed to promote problem based learning activities at Ulster University. Innovations in Education and Teaching International. 52:2. 218-228.

Healey, M., Flint, A. \& Harrington, K. (2014). Engagement through partnership: studentsas partners in learning and teaching in higher education. York: HEA. Retrieved from https://www.heacademy.ac.uk/engagement-through-partnershipstudents-partnerslearning-and-teaching-higher-education 
HEA (2012). Student retention and success change programme: Implementing and evaluating the impact of the 'What works?' programme. Retrieved from https://www.heacademy.ac.uk/workstreams-research/themes/retention-andsuccess/what-works-student-retention-and-success-change

HEA (2014). Framework for partnership in learning and teaching in higher education. York: HEA. Retrieved from https://www.heacademy.ac.uk/students-partnersframework-action

Higher Education Funding Council (2008): Report of the HEFCE Leadership, Governance and Management Fund supported project LGMF 101 Managing a substantial increase in on-campus student employment. A forthcoming challenge for HR management and leadership. Retrieved from http://catpages.nwmissouri.edu/m/lgmf/index.html

Jones, G. (2012). Supporting Staff to be Supporters. In M. Morgan (Ed), Improving the Student Experience: A practical guide for universities and colleges. Oxon: Routledge.

Keenan, C. (2014). Mapping Student-led Peer Learning in the UK. York: HEA. Retrieved from

https://www.heacademy.ac.uk/sites/default/files/resources/Peer_led_learning_Kee nan_Nov_14-final.pdf

Kvale, S. (2007). Doing Interviews. London: Sage.

McGregor, D. (1960). The Human Side of Enterprise. New York: McGraw:Hill

Mezirow, J. (1991). Transformative Dimensions of Adult Learning. San Francisco, CA: Jossey-Bass.

NUS (2012). Manifesto for Partnership. Retrieved from http://www.nusconnect.org.uk/news/article/highereducation/Rachel-Wenstonelaunches-a-Manifesto-for-Partnership/

Nygaard, C., Brand, S., Bartholomew, P. \& Millard, L. (2013). Student Engagement: Identity, Motivation and Community. Oxfordshire: Libri Publishing.

O’Donoghue, T. (2007). Planning your Qualitative Research Project: An Introduction to Interpretivist Research in Education. Abingdon: Routledge.

Perna, L. (2010). Understanding the working college student. Virginia: Stylus publishing.

Pintrich, P.R. \& Schunk, D.H. (2002). Motivation in Education: Theory, Research and Applications. Upper Saddle River, NJ: Merrill-Prentice Hall.

Prosser, M. \& Trigwell, K. (1999). Understanding Learning \& Teaching: The experience in Higher Education. Buckingham: Open University Press.

QAA (2009). Rethinking the values of higher education - consumption, partnership, community? Quality Assurance Agency. Retrieved from http://www.sparqs.ac.uk/ch/F2\%20Rethinking\%20the\%20Values\%20of\%20High er\%20Education.pdf

QAA (2012). UK Quality Code for Higher Education - Chapter B5: Student engagement Retrieved from http://www.qaa.ac.uk/publications/information-andguidance/publication?PubID=174\#.VHSYwWd_vms

Van Schalkwyk, S., Cilliers, F., Adendorff, h., Cattell, K. \& Herman, N. (2013). Journeys of growth towards the professional learning of academics: understanding the role of educational development. International Journal for Academic Development, 18:2, 139-151, DOI: 10.1080/1360144X.2012.673490

Savin-Baden, M. \& Howell Major, C. (2013). Qualitative Research: The essential guide to theory and practice. Abingdon: Routledge.

Thomas, L. (2002). Student Retention in higher education: the role of institutional habitus. Journal of Education Policy, 17, 4:423-42. 
Thomas, L. (2012). Building student engagement and belonging in Higher Education at a time of change: final report from the What Works? Student Retention \& Success programme. Retrieved from https://www.heacademy.ac.uk/node/2932

Ulster (2013) Learning and Teaching Strategy, 2013/14 -2017-18. Retrieved from http://www.ulster.ac.uk/tls/

Vaughan, S, E. \& Williams, G. (2013). Student Engagement with Learning Resources in Art \& Design: Seeding Possibilities. In C. Nygaard, S. Brand, P. Bartholomew \& L. Millard (Eds.) Student Engagement: Identity, motivation and community (pp.17-33).Oxfordshire: Libri Publishing.

Welikala, T. \& Atkin, C. (2014). Student co-inquirers: the challenges and benefits of inclusive research. International Journal of Research and Method in Education, 37:4, 390-406, DOI:10.1080/1743727X.2014.909402 